\title{
MORE ALIVE THAN ALL THE LIVING: Sovereign Bodies and Cosmic Politics in Buddhist Siberia
}

\author{
ANYA BERNSTEIN \\ University of Michigan
}

In August 2009, Russian president Dmitry Medvedev was declared by Buryat Buddhists to be an embodiment of the Buddhist goddess White Tara. Pandito Khambo Lama, the leader of Buryat Buddhists, made the declaration during the president's official visit to the Ivolginskii monastery in eastern Siberia. The news caused a storm of controversy among metropolitan Russian intellectuals: from the left, decrying such unseemly alliances between church and state, and from the right, over the choice of the church in question, proclaiming that a "Russian Orthodox president" cannot also be a Buddhist goddess. In Buryatia, however, where a long tradition exists of binding Russian emperors to the most popular female deity in the Tibetan Buddhist pantheon, the announcement was received as a logical continuation of local practice. Although some considered such a "nomination" an obsequious and politically opportunist gesture or, conversely, an ultimate recognition of Russian sovereignty over Buryats (a Mongolian people who number some 450,000 across Russia), other local leaders viewed this as a reverse "incorporation" — not of Buryatia into Russia, but of Russia into the larger Buddhist cosmos through laying claim to the president's body.

The summer of 2009 turned out to be quite eventful for Buryatia, a relatively trouble-free Siberian multinational region. Although officially a semiautonomous republic within the greater Russian Federation, Buryatia again made headlines when the Constitutional Court of Russia required it to remove all references to “sovereignty” from its constitution. Eighteen years after President Boris Yeltsin’s 
famous invitation to Russian regions to "take as much sovereignty as you can swallow," this order signaled a significant reversal of the freedoms promised during perestroika. It also signified that the relations between Russia's political center and its diverse populations are once again being redefined as the central government reconsiders just how "multinational" it wants to be in an age of authoritarian revival.

Here I wish to demonstrate that the case of "president as goddess" is only one recent instance of a long-running Buryat ritual traffic in bodies, which can both conform to and diplomatically challenge Russian logics of political rule. I describe elsewhere how the extraordinary ebb and flow of revolutionary events since 1917 became crystallized in the bodies of specific Buryat monks, whose incarnations and reincarnations adroitly captured the parallel refashioning of secular space experienced by all Buryats (Bernstein n.d.). Some of these monks once traveled to Mongolia and Tibet to receive a religious education, then adapted quite flexibly to the Soviet internationalist project after 1917 and, in turn, moved quickly to reestablish ties with the Tibetan community in exile in India after the end of socialism. During moments of rapid social transformation, such as the Russian Revolution, the Cold War, and the dissolution of the Soviet Union, certain bodies became key sites through which Buryats have negotiated their relationship with the Russian state and the larger Eurasian world. During my field research in Siberia and India, I encountered a variety of such metonymic bodies - the dead bodies of famous monks, the temporary bodies of reincarnated lamas, the celibate bodies of Buddhist monastics, the dismembered bodies of lay disciples offered to the spirits, and finally, the Russian leader's body, which has historically been a key site for uniting competing universes of meaning and creating flexible political alliances.

My argument is based on the premise that to maintain their long-standing mobility - across spatial borders of nation-states and temporal horizons between life and death - Buryats employ a characteristically Buddhist "body politics." This is an assertion of cultural sovereignty that also allows Buryats to preserve a careful balance between a greater Eurasian Buddhist cosmos and their loyalties to Russia. Through such religious practices, nationalist-minded Buryat Buddhist leaders and their lay followers - the main protagonists of this article - are fundamentally reshaping the biopolitical boundaries of sovereignty in postsocialist Russia and, in so doing, developing a hybrid subject position that often falls outside the conventional anthropological categories for discussing religious practice during and after socialism. This article is thus intended as a contribution to three theoretical areas: the growing literature on socialist and postsocialist body politics (Borneman 2004; Gal 


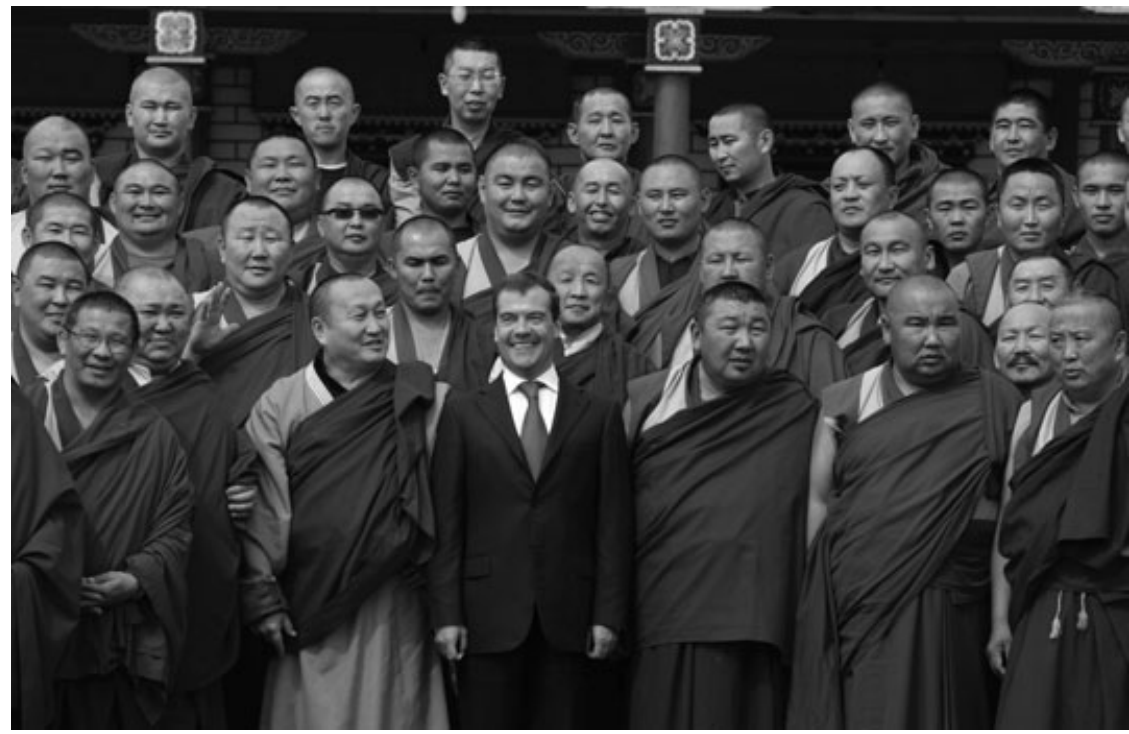

FIGURE 1. Russian president Dmitry Medvedev with the lamas of Ivolginskii monastery, shortly after Medvedev's nomination as the White Tara, August 2009. Printed with permission of RIA Novosti.

1991; Todorova 2009; Tumarkin 1997; Verdery 1999), cross-disciplinary studies of sovereignty that focus on the body as a site of sovereign power (Agamben 1998; Foucault 1980; Hansen and Stepputat 2004), and the emergent field of anthropology of religion and postsocialism (Balzer 2005; Grant 2011; Luehrmann 2011; Pedersen 2011; Rogers 2005; Steinberg and Wanner 2008). I work with the notion of sovereignty on three distinct levels: sovereignty of an individual body, biopolitical sovereignty exercised by nation-states, and “cultural” sovereignty asserted by minorities. The theoretical focus here is sovereignty of an individual body, specifically Buryat Buddhists' notions of an ideal sovereign body, and on demonstrating how these bodies play out in the politics of cultural sovereignty.

As President Medvedev's body already begins to tell us, bodies, understood here in the most broad sense as "contingent formations of space, time, and materiality” (Lock and Farquhar 2007:1), often figure prominently in performances of sovereignty across cultures. Most famously, sovereignty has been linked to bodies of leaders, who were believed to have two bodies: a body natural and a body politic (Kantorowicz 1957). Although the context of medieval kingship might no longer be relevant, Kantorowicz's notion of the "two bodies of the king” remains a foundational point of translation in thinking of how bodies of present-day leaders often become sites for assertions of sovereignty. Shifting attention from leaders 
to ordinary people, more recent studies have focused on these bodies as sites of performance of sovereign power, sites that become most visible in extreme conditions, such as war and other states of exception (Agamben 1998; Foucault 1980). Exploring these ideas, scholars have argued that besides being an object of sovereign violence, the body can also be an ultimate site of resistance, as exemplified by the figure of a civil disobedience campaigner, a hunger striker, or in the extreme, a suicide bomber (Hansen and Stepputat 2004). Yet what seems to be missing from these accounts of "sovereign bodies" — a broad notion that includes a range of historical actors, "from states, nations, communities, self-appointed big-men and leaders, to mobile individuals and political outfits" (Hansen and Stepputat 2005:5) - is the sense of how culturally specific conceptions of sovereignty of an individual body might become metonymic for broader political and even cosmic processes. Furthermore, the aforementioned portrayals of bodies as sites of stubborn resistance are usually based on the long-standing Western liberal idea of a self-owning individual with clear notions of the self and of the individual body: therefore, the violation of its physical boundaries constitutes an act of transgression. ${ }^{1}$

The Buryat case reveals a very different paradigm of body sovereignty, one that runs counter to the common notions of body integrity and self-ownership, instead being influenced by Buddhist concepts of the body. In this light, bodily sovereignty needs to be conceptualized beyond the issues of boundaries and property, as cultural understandings of sovereignty are frequently inseparable from specific religious and metaphysical concepts. The physical body, in a pan-Buddhist view, is not an “independent entity set against others, 'me' contrasted with and in opposition to 'you,' but is just the coming together in a patterned heap of a collection of material elements," where the patterning is defined by karmic processes over time (Williams 1997:207). This notion of the body is intricately connected to the Buddhist doctrine of "no-self, " which holds that what we perceive as an unchanging and permanent "self" is a constantly changing collection of elements that constitute a psychophysical complex, which is conventionally understood as a "self." In the Buddhist view, this self is an illusion, falsely imagined to exist somewhere among the various constituents of mind and body. By this logic, the ownership of one's own body is theoretically impossible, because there is no entity, such as a permanent "self" or "I" that could claim ownership. Sovereignty, in the Buddhist sense, is achieved not through claiming the boundaries of one's body but through using one's body as a vehicle to reach enlightenment. Although in Buddhism the body is often viewed as repulsive and disgusting, something to which people erroneously 
cling and that should be overcome through special training, such as mediations on the foulness of the body, the human body is also valued as the best vehicle for traversing the path to enlightenment (Collins 1997; Williams 1997). Mastering death, in particular, offers an especially striking way to sovereignty in a Buddhist context.

Death, one of the four main forms of human suffering in Buddhist thought (along with birth, old age, and sickness), "exemplifies the very problem that the Buddhist soteriological project is to overcome" (Cuevas and Stone 2007:1). The idea of stopping the cycle of "unsatisfactory rebirths" and attaining nirvana signifies the defeat not only of desire and attachment but also of death, demonstrated by the Buddha, who was the first "to attain to the deathless" (Cuevas and Stone 2007:1). Other Buddhist methods of control over death include particular techniques of the body, such as the ability of some extraordinary individuals to control their future rebirths (incarnate lamas) or to stop the decomposition of their bodies after death ("incorruptible" bodies of certain saints and yogins). In what follows, I engage with contemporary forms of these long-standing Buddhist corporeal technologies to demonstrate how Buryat practices of sovereignty have come to be forged through these exemplary bodies. I explore a particular notion of bodily sovereignty that, I believe, lies at the heart of these assertions, one that might explain why contemporary cosmic politics is centered around what some Buryat Buddhists construct as "ideal sovereigns" — bodies that are fluid, mobile across time and space, and transgressive of geopolitical borders and, ultimately, of death. Their sovereignty comes not from self-ownership or bodily integrity but, rather, from a person's ability to incorporate and be incorporated into various nonhuman agents, as well as to master the biological processes of birth, death, and rebirth.

"Transgression," indeed, appears to emerge as a common trope through which one can explore how particular Buryat uses of the body can challenge and sometimes even defy sovereign power. Here, I do not use the term transgression in terms of long-standing explorations of religious notions of negation and taboo (Bataille 1991; Taussig 1998) but in the sense of creative openings that such uses of the body can produce in the workings of larger sovereignties. I organize my discussion around three types of transgression that I believe capture the common threads in local constructions of what might constitute a sovereign body in a post-Soviet Buddhist context: (1) incorporation and fragmentation (transgression of body ownership and integrity), (2) unauthorized mobility (transgression of geopolitical borders), and (3) and transcendence of death (biopolitical transgression). 
I begin by outlining Buryats' location vis-à-vis two major Eurasian powers: that of the Russian state in its various incarnations and that of the cosmopolitan Tibetan Buddhist world. I then look at how Soviet secularization, to which Buryats were exposed for most of the 20th century, made the body its main biopolitical battleground. Finally, I draw on fieldwork conducted in Buryat and Tibetan communities in Russia and India from 2001 to 2008 to examine the specific Buddhist techniques of the body that enabled certain individuals to escape sovereign violence.

\section{EURASIAN SOVEREIGNTIES}

As early postperestroika hopes for Buryat territorial sovereignty were slowly eroding, indigenous politics reorganized itself around claims usefully defined elsewhere in terms of "cultural sovereignty" — a broad notion signifying strategies to maintain and develop cultural alterity, as well as assert autonomy from external control (Coffey and Tsosie 2001). Such expressions of sovereignty are usually disaggregated from territorial nationalism and are primarily nonjuridical and strategic; they are often executed on equal footing but in interdependence with other sovereignties (Cattelino 2008; Winegar 2006). Cultural sovereignty discourse has become especially vital for Buryat leaders after the collapse of the USSR, as, against the earlier hopes of indigenous elites, their marginality seems to have been enhanced in post-Soviet Russia. Having long been discursively defined by others as belonging to the various peripheries, such as those of empires and states-Mongolian, Chinese, Russian, Soviet, and now, the Russian Federation-most recently Buryats have unexpectedly found themselves pushed into yet another cultural fringe, this time that of the cosmopolitan world of Asian Buddhism. Almost equally removed from Moscow as from Lhasa, Buryats are a minority not only within larger Russia (despite being the largest ethnic group in Siberia) but also within the nominally autonomous republic, which bears their name but where they now constitute only 25 percent of the population. Despite their eagerness to reestablish ties with their Asian coreligionists, in a transnational context, they are often cast as the northernmost fringe of the "forest" Mongols, who received Tibetan Buddhism much later than most of their Asian counterparts, subsequently undergoing mass Russification and sovietization - a final blow to an already "incomplete" religious transmission. In particular, many in the Tibetan exile community consider Buryats' current attempts to revive their Buddhist traditions to be of dubious authenticity, and they think Buryats are in need of Tibetan "missionaries" to help them with this task. In this context, a major arena where assertions of cultural sovereignty take place today is the contemporary practice of Buryat Buddhism, which many local leaders 
consider the most important cultural currency. Thus, what is at stake in such regionally particular religious domains is not only Buryats' relationship with the Russian federal government and the phenomenon of the so-called "regional" sovereignty but also the issue of cultural recognition within the larger Mongol-Tibetan world.

In addition to a complex and uneasy engagement with Tibetan Buddhists across Asia (and now the world), Buryats have a relationship with the Russian state that is fraught with contradictions. Despite Buryats' long-standing transnational orientations, the Russian government's regular strategy since imperial times was to restrain Buryat Buddhists from contact with their foreign coreligionists. In 1764, Empress Catherine the Great granted an arguably independent (which many today interpret as "autocephalous") status to Buddhism, a non-Russian religion in the sensitive borderlands, for which she reportedly had been proclaimed the first Russian reincarnation of the Buddhist goddess White Tara. By cutting Buryats' ties with their coreligionists in Mongolia and Tibet, this move seemingly ensured the successful incorporation of Buryats into the empire.

Subsequently, Buryats have been subjected to the various policies of the Russian imperial, later Soviet, and now postsocialist Russian federal government. For all the changes, the center's reluctance to see its Buddhist subjects cross borders has remained and continues. In 2000, Vladimir Putin's National Security Strategy identified foreign religious organizations as an explicit threat to stability. At the Ivolginskii monastery in 2009, his successor Medvedev stated that no help "from abroad” was needed to permit Russia's Buddhist peoples to rebuild monasteries destroyed during Soviet times (Anonymous 2009a).

\section{SOVIET SECULARIZATION AS BIOPOLITICS}

The Soviet Union, although not usually invoked in discussions of biopolitics, certainly exemplifies how governments produce subjects and manage human populations through regulating health, hygiene, diet, and sexuality (my use of the notion of "biopolitics" here is consistent with Foucault 2003:239-264). The Soviet body was highly regulated, as the socialist state attempted to greatly diminish private space through various surveillance institutions where bodies were permanently put on display (Buck-Morss 2000:199). Much literature has been devoted to the production of the New Soviet Person, especially in the domains of health, physical culture, and gender. The Soviet body was conceptualized as a machine: strong, masculine, productive, autonomous, and subject exclusively to reason (Attwood 1990; Livers 2004; Starks 2008). 
Although the workings of biopolitics in these domains have been well studied, the religious domain has been relatively neglected. Unlike secularization in the West, Soviet secularization attempted to expel religion not only from the public space but also from the body. Whether or not it was fully successful is still debated by scholars, with convincing evidence that religious life actively continued in the private sphere (Dragadze 1993; Steinberg and Wanner 2008). What matters here is that there was a serious and sustained attempt to create what I call "closed" bodies, whose sovereignty would be based on physical and moral strength, autonomy, and its impenetrability to religious influences. Religion was viewed as a literal "opium" for the body that was not to be ingested orally or intravenously; it was conceptualized as a disease that might eventually destroy the body. In particular, religion was related to the classical biopolitical concern with health and hygiene, as the kissing of Orthodox icons could transmit infections, and Central Asian Muslim veils were claimed to cause birth defects (Starks 2008:32). Lamas were accused of spreading unsanitary conditions, because of their adherence to the Buddhist doctrine of nonviolence, which supposedly did not allow them to kill lice. According to one atheist cultural worker, lamas also prevented believers from using soap to wash their hands and clothes, because of the "savage superstition" that happiness is washed away with the dirt (Erbanov 1959:27). Although hygiene can be viewed as surface purification, the body also had to be purged from the inside: of supernatural abilities, spirits, and deities that might inhabit it. Siberian shamans have been thrown off helicopters to see if they can "really" fly (Vitebsky 1995:136). Incarnate lamas were convinced to renounce their status as false (Norbaev 1927). ${ }^{2}$ Monks, in particular, presented a biopolitical hindrance, because they refused to participate in sexual reproduction and socialist labor.

This biopolitics also affected mobility, as fears of contamination of bodies by alien ideologies became an additional justification for the Iron Curtain. To be allowed to travel abroad, one had to pass the test of ideological solidity. The permeable bodies of religious adepts, which might emanate divinities or allow deities to penetrate them, had to be first purified and then closed or, in the case of resistance, destroyed. In this context, some aspects of Soviet secularization can be viewed as a kind of hygienic treatment to expel extraneous agents and religious subjectivities and dispositions, as well as a subsequent symbolic "closing" of the body in at attempt to constrain and circumscribe it in strictly materialist and unitary terms. Here, the Soviet purification was only partially successful: it is specifically the bodies that resisted such practices that would become key sites in postsocialist assertions of cultural sovereignty. The bodies of the Buddhist lamas that I turn to 
now stand in stark contrast to the Soviet secularized body: mobile, permeable, and enduring, they have become productive arenas for the creative refashioning of what it means to be sovereign.

Taking a close look at several such bodies that I encountered during my field research in Russia and India, I pose two questions: how do these political claims come to be enacted through actual uses of the body, and what specific conceptions of body sovereignty emerge from these practices? As stated earlier, the transgressions of bodily boundaries, geopolitical borders, and lines between life and death appear to figure prominently in debates on cultural sovereignty in Buryatia. I begin with the last of these three, not least for reasons of the prominence of the postsocialist biopolitics of death in the formerly socialist world.

\section{MORE ALIVE THAN ALL THE LIVING}

Dead bodies have long animated the study of politics in the postsocialist world, as convenient vehicles to rewrite history, reorder time and space, and reorient the present (Borneman 2004; Gal 1991; Todorova 2009; Verdery 1999). These highly influential studies, however, do not question the present-day ambiguity and biopolitical negotiations of death, which create liminal beings, who hover between life and death, being neither persons, nor cadavers. Although these issues have been richly explored by medical anthropologists (e.g., Kaufman and Morgan 2005), the religious dimensions have received less attention.

Consider one such case of a key religious body in Buryatia and its political ramifications. In September 2002, lamas of the Ivolginskii monastery accompanied by independent forensic experts exhumed the body of Dashi-Dordzho Itigelov, the last Khambo Lama elected during the Russian empire, who died in 1927. The body of the lama found lying in the lotus position allegedly did not deteriorate, and soon rumors spread that the lama was alive and had returned to Buryatia, as he had promised. According to the stories told by senior monks, before his death, Itigelov asked to have his body exhumed 30 years later. He was first exhumed secretly in 1955 (a little short of 30 years) by his relatives and lamas out of fear of being discovered by the Soviet authorities. The body was intact, so they reburied him right away. In 2002, he was exhumed again. Since then, the lama's body has been encased in a glass display at the Ivolginskii monastery and shown to the public eight times per year on major Buddhist holidays.

Today debates regarding the state of his body continue. Many, including the Buddhist leadership and some Russian and Buryat academics, maintain that Itigelov is simply alive, in ways yet unknown to modern science. Reports of 
Itigelov's growing nails, hair, and allegedly warm body temperature consistently make headlines in the local and national press. Those who are more careful claim that he is neither dead, nor alive, being in a special state of deep Buddhist mediation. Yet others claim that he did die, reaching the state of nirvana and stopping the cycle of rebirth, but he deliberately left his incorruptible body behind, knowing in advance that only a magical feat such as his would inspire strong faith during these difficult postsocialist times. To many believers, Itigelov's body, said to have magical powers to grant any sincere wish and instantaneously correct one's karma, is a beacon of hope. During my last visit in 2008, pilgrims stood in long lines stretching out from the monastery gates across the rolling steppe to touch his body during the special days when he was displayed. (On most days, the body was hidden upstairs, and a thread tied to his body ran through the ceiling down to the altar, so the visitors could touch it instead. $)^{3}$ To the leading Buryat Buddhist organization, the Buddhist Traditional Sangha of Russia, however, Itigelov is a guarantee of its avtokefal'nost' (autocephality), because he is a fully local leader who had never traveled to Tibet for religious training and yet achieved such remarkable realizations.

"Why do we Buryats always try to bow in front of foreigners? Some Buryats see a Tibetan and immediately think, 'a guru!' Look at Itigelov- he never went anywhere," the Khambo Lama, current leader of Buryat Buddhists, told me. ${ }^{4}$ Itigelov, he said, has engineered his "return" himself to arrive in Buryatia during these troubled postatheist times.

The incorruptible body has a long history in Buddhism, most famously in the Lotus Sutra. Such famous figures as Tsongkhapa were said to have incorruptible bodies. Mummification of great lamas, such as the Dalai Lamas, has also been an important practice that continues in Tibetan exile communities with the mummification of the current Dalai Lama's senior tutor Ling Rinpoche. In Itigelov's case, although there are some circulating rumors that salt has been used to preserve his body, the official point of view of the Buddhist Sangha is that his body is miraculously self-preserved and has not been deliberately mummified or embalmed.

Yet the notion of the preservation of the body of a leader as a display of sovereignty, exemplified by famous socialist corpses, such as those of Lenin, Stalin, and Mao, is not lost on Itigelov's commentators. Shortly after Lenin's death in 1924 and before the decision to embalm him was made, Soviet poet Vladimir Mayakovsky inadvertently created what would become a ubiquitous slogan posted in every classroom in the Soviet Union: 
Lenin i teper' zhivee vsekh zhivykh.

[Lenin is even now more alive than all the living.]

The same poem further specified the metonymic connections between Lenin and Soviet sovereignty vested in the Communist Party by what has become another famous slogan: "When we say 'Lenin' / We mean 'Party' / When We Say 'Party,' / We mean 'Lenin'” (Mayakovsky 2003). Similar to the metonymization of the "undead" Lenin into the sovereignty of the Party, Itigelov has come to embody the "autocephality" of Buryat Buddhism. Comparisons of Itigelov with Lenin are indeed ubiquitous in both Buryat and broader Russian media: from condemnations by those opposing Itigelov's display, who argue that Itigelov should be buried in a stupa (reliquary), ${ }^{5}$ to humorous quips by journalists, paraphrasing the above slogan as, "More Alive than All the Living: Not Lenin but Lama Itigelov" (the title of an article in Izvestiia, a high-circulation Russian daily newspaper; Klin 2006). Rumors, sometimes quite wild, relating socialist dead bodies to Itigelov continue to circulate: a tabloid recently claimed that Itigelov gave advice regarding Lenin's embalmment in 1924 (the Sangha lamas denied this claim; Anonymous 2006). Another journalist called Itigelov the "Buryat Lenin," while others argue that the lama's body is superior to Lenin's, because Itigelov does not need any special preservation or embalmment. Yet many popular news stories covering socialist dead body politics put Itigelov firmly alongside Lenin and Mao (Anonymous 2005, 2007). As life and death today are increasingly approached through their biopolitical negotiation, Itigelov joins the growing numbers of "liminal beings who hover in an ambiguous zone between life and death," similarly to "not-deadbut-not-fully-alive" biomedical subjects, whose personhood is negotiated through intersubjective knowledge (Kaufman and Morgan 2005:330). If sovereignty has to do with “making" live or "letting” die (Foucault 2003), Buryat Buddhists' ability to make decisions about life, death, and the different values of different (quasi) lives demonstrates how long-standing pan-Buddhist practices could be deployed as assertions of countersovereignty in the domain of cultural and cosmic politics.

Although Itigelov is undoubtedly the most famous Buddhist body in Russia, he is not the only Buryat lama who is believed to have overcome his own mortality. ${ }^{6}$ The stories of Buryat lamas defying death abound in contemporary Buryat folklore, often structured by the memories of violence inscribed in their bodies during the Soviet period, when lamas were sent to work in labor camps and were forced to marry against their beliefs. Monastic disciplines of self-denial, which produce ascetic 
bodies, as Foucault notes, are unlike other societal disciplines aimed at creating famously "docile bodies." The primary function of ascetic discipline, although it involves obedience to others, is to increase each individual's mastery of his own body, rather than to increase its productive utility (Foucault 1979:137). Those bodies, which did not comply with the new requirements of obligatory labor and reproductive sexuality, constituted a biopolitical threat to the socialist state. By displaying noncompliance, those bodies were to be destroyed, purged without a trial. Or were they?

"When I aimed my gun at the lama and was about to pull the trigger, the lama just disappeared," said the Soviet guard at a labor camp, who was ordered by his superiors to shoot a lama in 1937. "After a few seconds, he appeared again, but he was about thirty steps from the place where he was before. I quickly aimed and shot again. The lama again disappeared! After some time I saw him floating in the air, over the pine tree tops, I shot at him again. My hands were shaking, I was overcome by the panic and the fear. All of a sudden the lama appeared again, close to me, stretching his hands towards me and saying something. I vaguely remember that I reloaded my gun and shot again. The lama fell on the ground, his chest was covered with blood. Suddenly a white lotus flower of giant dimensions appeared in the air. Its aroma was so strong that I started feeling dizzy. I can't remember anything else.” .. . This guard ended up in a psychiatric hospital and later is reported to have become very religious, sending one of his sons to be a monk. [Mukhanov 2005:199-200]

Stories about undying or disappearing lamas, escaping Soviet persecutions such as this, that have been recently recorded among Buryat villagers by a local folklore enthusiast, are widespread in Buryatia. ${ }^{7}$ Another story tells of a lama who was arrested, beaten up, and thrown into a barred military car, but was nowhere to be found on arrival to the prison. Instead, a Tibetan sacred book was left in his place. Arrested lamas are said to walk through walls of prisons right in front of their astounded guards; it is also claimed that they disappear into thin air on their escape route to China and Mongolia.

Besides miraculously preserved bodies and bodies that miraculously escaped, a variety of other Buddhist techniques allow some Buddhist individuals a degree of control over their own mortality. The stories of escapes point to a certain kind of unauthorized mobility, which silently defies the logics of larger sovereignties, such as the Russian state, which, for all its incarnations, frowns when its minorities develop transnational relationships bypassing the state. Yet Buddhist corporeal 
technologies of reincarnation and emanation also produced contesting ideas of sovereignty, enabling illegal border-crossings between the hostile socialist states of the Soviet Union and China, and contributing to linking north and south Asia in the postsocialist period.

\section{INCORPORATIONS}

Buryat Buddhists, like many in the Tibetan religious world, believe in a capacity of certain people to "emanate" or embody a particular divinity or highly advanced master. It was first applied to religious figures, such as the Dalai Lamas, who are understood to embody Avalokiteshvara (the bodhisattva of compassion) and Jebtzundampa Khutugtu (the former spiritual leader of Mongolia), an emanation of Vajrapani. Transferring the notion of emanation into the secular realm, Tibetan Buddhists also proclaimed sacralized historical figures, such as the three "dharma kings" of Tibet, to be manifestations of deities. Subsequently, Genghis Khan was considered a manifestation of Vajrapani, Qing emperor Qianlong an emanation of Manjusri, and Russian empress Catherine the Great an emanation of the White Tara (subsequently, all Russian emperors, whether male or female, were considered emanations of the White Tara).

Catherine the Great is said to have received her title after she granted an "autocephalous" status to Buryat Buddhism, removing the possibility of foreign allegiances to Mongolian and Tibetan religious hierarchs, and seemingly ensuring the successful incorporation of Buryats into the empire. From the Buryat point of view, however, as recently argued by prominent native intellectual and scholar Nikolai Tsyrempilov, the title given to the empress was, rather, an example of the use of the Buddhist "skillful means" doctrine (upāya) _ a key Mahāyāna doctrine that facilitated the propagation of Buddhism - to advance the dharma to the "West" (European Russia). Thus, some Buryats may present a competing view of "incorporation." From this perspective, Russia had been drawn into the "pax buddhica" by claiming the empress's body (Tsyrempilov 2009). These debates received an unexpected continuation after the announcement of Medvedev as an emanation of White Tara. By being extended into contemporary Russia, Medvedev's White Tara title is not a sign of defeat and submission but, on the contrary, signifies the incorporation of Russia (embodied in the president) into the Buryat symbolic world.

Naming Medvedev as the White Tara appears to be the idea of the Khambo Lama Aiusheev, who has been known to idealize Buryats' past as part of the Russian empire. In 2008, he mentioned to a group of scholars, in which I was present, that 
he considered Vladimir Putin an embodiment of the White Tara. Putin, however, never visited Buryatia, and so the first president to visit Buryatia was Medvedev in 2009. He personally met with the Khambo Lama, toured Ivolginskii monastery, and left "impressed" with the body of Itigelov. According to the press, Medvedev refused to sit on the "White Tsar" throne and let the Khambo Lama prostrate in front of him (the ritual that the Khambo Lama claims dates back to the Russian Empire), but the Khambo Lama's nomination of Medvedev to White Tara was still made (Anonymous 2009c). The reactions to this news generated a storm of controversy, with some Buryats considering this gesture to be obsequious and humiliating, while others affirmed it was a necessary political alliance that would improve relations with the federal center. ${ }^{9}$ The realpolitik point of view still seems to prevail in local discussions, although events that followed the nomination made many Buryats wonder if the Khambo Lama's realpolitik was indeed in the interests of the republic.

Since 2000, the Russian Constitutional Court has been involved in the struggles to remove sovereignty clauses from the constitutions of Russia's 21 ethnic republics. It has been declared that there could not be two levels of sovereign power within the Russian Federation (Article 10P of the Russian Constitution, June 7, 2000). During the early 2000s, some republics, including Buryatia, followed this order (Anonymous 2002). However, many constitutions included another clause that could be interpreted as a claim to sovereignty: the statement that the people of the republic were a "source of power." This clause remained in most republics' constitutions until the summer of 2009, when the Constitutional Court revisited this issue, stating that the people of the republic cannot be the source of power, because the only source of power is the "multinational people of Russia." At that time, Buryatia, along with Tatarstan, Bashkorkostan, Kabardino-Balkaria, Komi, and Chechnya, were ordered to remove the respective clauses from their constitutions. In Buryatia, the sovereignty clause was indeed dropped soon after during a session of Narodnyi Khural, the legislative body of the republic (Anonymous 2009b).

Yet some would argue that declaring the president as a Buddhist deity is not necessarily counterproductive to the struggle for Buryat sovereignty, if the latter is perceived as disaggregated from territory. Some Buryats consider the phenomenon of "regional" sovereignty within Russia to be almost meaningless, as it is severely limited in crucial ways. Recognizing these limitations, for some time now indigenous politics has focused on issues of recognition and difference. Viewed in this light, the declaration of the president as White Tara is interpreted by some Buryat Buddhists as contesting their peripheral status, demanding greater 
visibility and cultural recognition within larger Russia, all of which are key to cultural sovereignty. The debates around this nomination reveal how bodies viewed as sovereign can produce contesting political claims. The president's body, a quintessential sovereign phenomenon, in this light, emerges not as autonomous and self-owning, but as a corporeality integrated with nonhuman Buddhist agents. The capacity of sovereign bodies to incorporate and be incorporated into other essences in the Buddhist context is perhaps most starkly revealed in the phenomenon of incarnate lamas - these extraordinary individuals with the highest status in Tibetan Buddhism. I now turn to an example of how incarnate bodies combine many of the capacities for transgression outlined above: transcendence of death, the ability to incorporate other beings, and finally, unauthorized mobility across time and physical space.

\section{SOVEREIGNTY REINCARNATE}

Early Buddhist theology postulated that the Buddha had two bodies - the physical body (rüpakāya) and the transcendent body "of virtuous qualities" that was not subject to sickness and death ([dharmakāya]; Lopez 2002:61-62). Later doctrines developed a tripartite scheme of the Buddha's bodies: dharmakāya, in which the supramundane qualities of the Buddha evolved into a kind of transcendent principle of enlightenment; the sambhogakaya, a celestial body of the Buddha; and the nirmanakāya or "emanation" body, which might be assumed for the purpose of instructing and saving living beings, most famously taking the form of the historical Buddha himself (Williams 1989:167-185). In Tibetan Buddhism, the reinterpretation of the notion of nirmanakaya combined with the political developments in Tibet's relations with the Mongols and Chinese resulted in the development of the institute of tulkus (sprul sku; lit. "emanation body") or incarnate lamas, who came to rule in central Tibet in the 17 th century. ${ }^{10}$ Incarnate lamas - the most famous of whom today is the Dalai Lama - are believed to be a line of individuals who are in a sense the same person, returning to the world lifetime after lifetime.

The permeable and mobile bodies of incarnate lamas, who can move through time and through the borders of nation-states, have long presented a challenge to socialist biopolitics. Consider, for example, contemporary struggles over the Dalai Lama's next reincarnation: in recent years, the Chinese government has made repeated claims that no lama would be reincarnated without the government's approval. The Dalai Lama, on the contrary, declared that he would not be reincarnated in Chinese-occupied Tibet and might even end his own line of reincarnation 
to avoid succession crisis. During my field research, I met incarnate lamas, whose very rebirth is due and at the same time bypasses tumultuous events of the 20th century, such as the Russian and Chinese Revolutions and subsequent secularization campaigns.

An interesting case in point here is that of Galsan Legden, a Buryat monk who left Siberia in 1927 to study in Tibet and whose remarkable biography I assembled in a somewhat piecemeal fashion through the oral histories with several Tibetan lamas. ${ }^{11}$ His formidable journey, which took more than a year of overland travel, started in the Buryat-Mongol Soviet Socialist Republic, passing through Mongolian grasslands, the Gobi Desert, and the high mountain passes of the Tibetan plateau. On his arrival in Lhasa, he enrolled in the Drepung monastery and soon rose to unusual prominence, becoming the first Buryat abbot of Drepung Gomang Monastic College. Having heard of Soviet violence against lamas in Buryatia, he made a decision to stay in Tibet. Nonetheless, as the socialist project migrated from Soviet Russia to China, he was imprisoned by the communist Chinese and reportedly died in custody in the mid-1970s. Little or nothing was known about his fate in Buryatia until 1989, when the first Buryat lamas, newly mobilized by perestroika, began visiting Drepung again, by then re-created in southern India by Tibetan exiles. To their amazement, the first late socialist Siberian pilgrims were stunned to discover Galsan Legden in India, living, as he himself professed, in his new body. That is to say, Galsan Legden, who was found in the Indian Drepung in 1989, is believed to be a reincarnation of the former Buryat pilgrim.

It is said that before his death in prison, Legden asked his cellmate, a Tibetan, if he, Galsan Legden, could come and visit his family. Thinking that he was talking about the time when they would get out of prison, his friend cheerfully agreed. The friend's family subsequently became Tibetan refugees in Kathmandu, where Legden was reborn as one of their sons. He was later identified as an incarnate lama by Drepung monks, and he went to India to study, where he was discovered by post-Soviet Buryat pilgrims. The monk subsequently visited Buryatia, had reunions with his Buryat "relatives," and became an active member of the Buryat Buddhist revival. Crucially, he ushered in a new kind of body particularly revered today in Buryatia: a Tibetan lama with Buryat "roots." Such lamas are believed to blur classically ethnic characteristics, being simultaneously "Buryat" and "Tibetan." What might such corporeal fluidity, resulting from transnational reincarnations, signify? In 2008, while living in the south Indian Drepung monastery, I asked this young man how he himself understood this reincarnation process. 


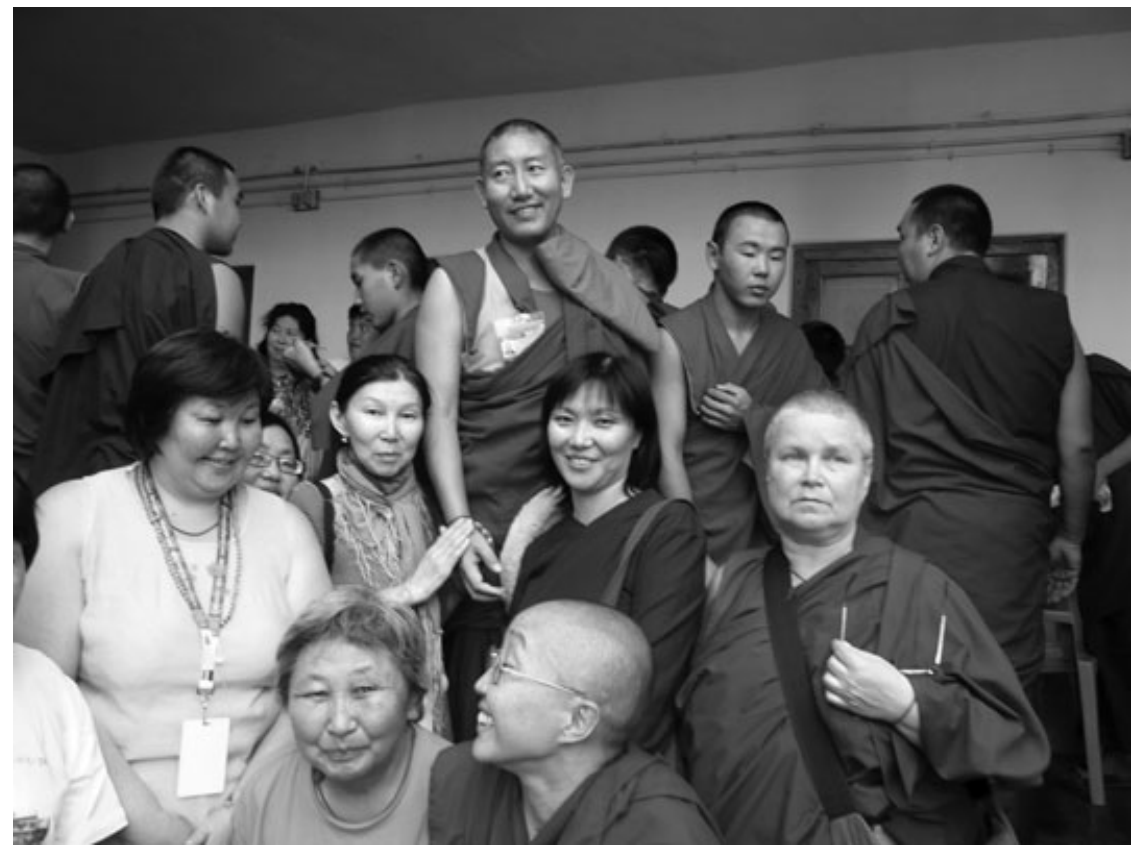

FIGURE 2. Buryat pilgrims with Shivalkha Rinpoche, another Tibetan lama with "Buryat roots.” Drepung Gomang monastery, South India, February 2008. Photo by the author.

When I was told I was a reincarnation of Legden, I was glad, but I didn't feel anything special. It was only when they showed me his picture, I felt something ... unusual. When they told me my predecessor was a Mongol—-I did not know about the difference between Mongols and Buryats at the time-I felt a sense of "us" and "ours." A sense of pride for being a Mongol, even a feeling of some kind of patriotism. A Mongol patriotism.

Only in the late 1980s, when Legden saw the first Buryat monks and pilgrims arriving in Drepung from Russia, did he learn that his predecessor was not a Khalkh Mongol but a Buryat. Since then, Legden became a major figure with Buryat Buddhists, both pilgrims to India and those at home.

One of the most important bodily rituals Buryat pilgrims perform while visiting Indian monasteries, in addition to prostrations and circumambulations, is getting blessed through touch by popular incarnate lamas. During such haptic engagements, spiritual power is believed to be transferred from the teacher to the disciple through a simple touch by the incarnate to the devotee's head, a gentle blow on the face, or the holding and reciting of consecrational verses over religious souvenirs. While I was living at the monastery, Buryats regularly requested audiences with Legden. 
The pilgrims who got blessings from him were viewed as spiritually charged, and on their return home, many people, in turn, wanted to touch them to partake of their accreted power. On a pilgrim's return home to Buryatia, the central ritual that took place was the distribution of objects that came in contact with Legden, which were given as tokens of attention to one's relatives and friends.

Yet far more spectacular and key functions performed by Tibetan incarnates are the rituals of the so-called empowerment (dbang). Through empowerment, lay believers are initiated into the practice of a particular deity ("deity yoga"). ${ }^{12}$ During this ritual the disciple must imagine the lama as a deity, and fellow disciples who attended the initiation led by the same lama are called vajra brothers and sisters (vajra, which literally means "thunderbolt," is one of the central symbols of Tibetan Buddhism). In some initiations, such as the Kalacakra cycle, disciples must visualize the master in sexual union with a female consort, subsequently visualizing themselves as entering the mouth of the lama, passing through his body to the vagina and then to the womb of his female consort, from where they are ritually reborn. Noting how the tantric pantheon is made up of multiple deity "families," anthropologist Martin Mills argues that this symbolism, misunderstood in the West as purely sexual, is in fact, also reproductive, aimed to generate alternative "kinshiplike structures" (2000:24). Initiation rites create new "families" based on religious lineages, with descent taking place from deities to incarnate lamas to lay believers. Although some Buryats regularly follow the Dalai Lama all over the world to receive empowerments, which he often confers on stadiums of believers, most cannot afford such distant travel. In such cases, lamas like Galsan Legden are asked to come to Buryatia to perform empowerments. Because Buryatia does not have any living incarnate lamas, tantric empowerments have become entirely the domain of Tibetan incarnates. Interestingly, those Tibetan lamas who are believed to be "Buryats" by virtue of their being incarnates of past Buryat masters are considered particularly suitable for this role, because Buryat believers already view them as their own "kin." How are we to understand the impact of such reincarnated bodies on the cultural politics in Buryatia?

Although Tibetan incarnate lamas are often considered the source of the highest authority in Buryatia, those of "Buryat descent" are thereby allowed to be detached from the usual Tibetan orbits and incorporated into the Buryat body politic. If reincarnation is a reproductive technology, where fictive kinship is created through all-male lineages (Mills 2000, 2002), the ability of key Buryat lamas to "father" descendants beyond the borders of their immediate nation-state reverses the traditional cultural hierarchy, in which Tibetans are regarded as superior for their 


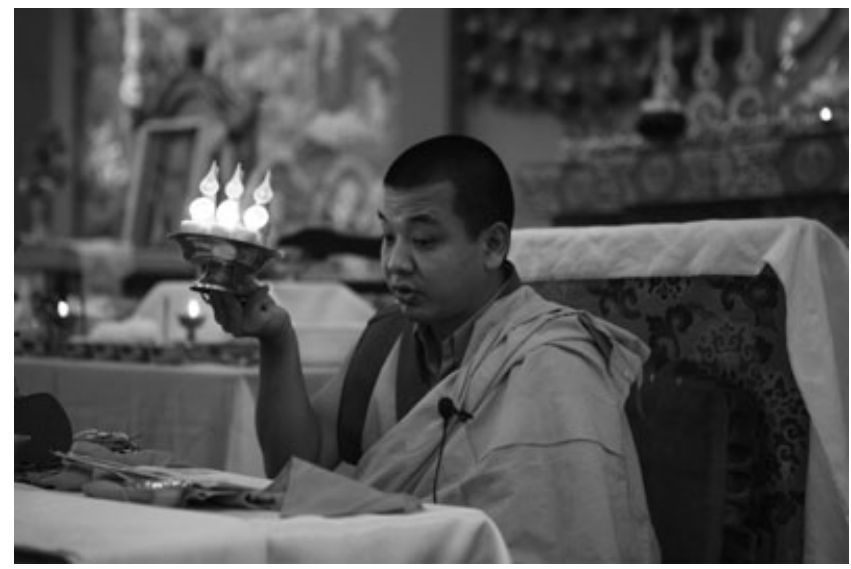

FIGURE 3. Kentul Rinpoche (Galsan Legden), performing a White Tara empowerment. Russia, 2008. Photo by Igor' Iancheglov. Printed with permission of Igor' Iancheglov.

more developed and ancient Buddhist culture. Instead, for some of the proponents of Buryat religious and cultural autonomy, the bodies of Tibetan incarnates with "Buryat roots" present sites of intensified sovereignty not only by virtue of their human-divine nature but also through viewing them as essentially "ours" (nashi). It is the ability of such lamas to cross boundaries, between nation-states, but also between life and death and conventionally defined lines of kinship and ethnicity that makes them crucial to the contested notions of sovereignty in Buryat political imaginaries.

Despite being ethnically Tibetan, the present Galsan Legden, by virtue of being a reincarnation of a Buryat monk, has become a key site for Buryat selffashioning. Not only was he the only Buryat to preside over the most famous Tibetan monastery, but he also mastered the process of death to be incarnated outside of Chinese-occupied Tibet to engineer his return to Buryatia, to relink ordinary Buryats with Buddhist deities as part of postsocialist religious revival. Incarnation here emerges as an empowering technology for mobility and border crossing. It also reveals a particular kind of a sovereign body that is able to control the processes of death and rebirth. Such sovereign bodies, however, are not autonomous and self-owning in the sense of being bounded, but instead reveal corporeal multiplicity unusual for Western contexts, as their sovereignty emerges from their incorporation of deities and previous lamas.

\section{CONCLUSION}

The two recent events in the Buryat Republic considered earlier - the attempt of the Russian state to curtail its authority and the declaration of Medvedev 
as the newest incarnation of White Tara - caused me to conclude that many of the long-standing questions about religious transformation across changing political economies and discourses of nationalism can be productively explored in the terms raised by recent scholarship on sovereignty and the body. I argued that the Buryat Buddhist body politics are particular expressions of cultural sovereignty through which Buryat believers are currently negotiating new subject positions in postsocialist Russia and the larger cosmopolitan Buddhist world. Theoretically, the case of Buryat body politics can enable us to reformulate ideas of body sovereignty beyond the standard notions of self-ownership and body integrity. I have considered several types of bodies, which, by virtue of being sites of resistance to sovereign violence, can themselves be considered sovereign: Itigelov who died shortly before the Soviet purges of lamas and managed to rematerialize after the end of socialism, "disappearing" lamas who escaped prison guards, and reincarnated lamas who transcended both death and Soviet and Chinese controls of mobility only to reemerge in postsocialist Buryatia. Despite the Soviet biopolitical legacies of secularization, which attempted to expel religion not only from the public sphere but also from the corporeal, producing symbolically "closed" bodies, the bodies considered here reveal permeability, fluidity, and the ability to incorporate and be incorporated into other beings and deities. Such bodies as those of Tibetan lamas, which contain "parts" of their "Buryat" predecessors; the Russian president's body, proclaimed to emanate from a Buddhist goddess; and Itigelov's body, believed to be in a state that is neither conventionally alive nor dead, become metonymic for broader geopolitical and cosmic processes, as they reorder hierarchies and produce contested sovereignties. It is perhaps for this reason that these "religious bodies politic" have become such productive sites for inscribing emerging values of Buryat cultural sovereignty as Buryats strive to define themselves in relation to-but on equal terms with — other sovereign bodies in a transnational Eurasian space.

\begin{abstract}
This article explores religious practice among Buryats, a Siberian people, through scholarship on sovereignty and the body. Under conditions of rapid social transformation such as those that accompanied the Russian Revolution, the Cold War, and the dissolution of the Soviet Union, certain religious bodies became key sites through which Buryats have negotiated their relationship with the Russian state and the larger TibetoMongol and Eurasian Buddhist worlds. Despite the Russian government's continuing reluctance to see its subjects cross borders, Buryats have maintained their long-standing mobility - across spatial borders of nation-states and temporal horizons between life and death - by employing characteristically Buddhist "body politics" that can both
\end{abstract}


conform to and diplomatically challenge Russian logics of political rule. Specific bodies constructed by some Buryat Buddhists as "ideal sovereigns" - bodies that are fluid, mobile across time and space, and transgressive of geopolitical borders and, ultimately, death - become metonymic for broader cosmic processes. [cultural sovereignty, body politics, religion, postsocialism, Eurasia]

\section{NOTES}

Acknowledgments. Special thanks to Bruce Grant, Donald Lopez, Nica Davidov, Lucas Bessire, George Hoffmann, two anonymous reviewers, and editors of Cultural Anthropology for their generous comments on earlier drafts of this article. The field research in Russia and India was supported by the Wenner-Gren Foundation and Fulbright Fellowship. The writing was supported by the Michigan Society of Fellows Postdoctoral Fellowship and Mellon/ACLS Dissertation Completion Fellowship. Versions of this article were presented as papers at the "Global Socialisms and Postsocialisms" Annual Soyuz Symposium (2009), Central Eurasian Studies Society Annual Conference (2010), and as a Noon Lecture at the Center for Russian, East European, and Eurasian Studies at the University of Michigan (2010). I thank the audiences of these events for their feedback and helpful suggestions. All English translations from Russian are my own.

1. Although self-ownership has been an important topic in feminist scholarship and public debate, it has been problematized by medical anthropologists who highlighted how the issues of commodification of body parts create aporias in Western understandings of body integrity and how theological notions of corporeal boundaries in crosscultural contexts might create obstacles to bodily fragmentation (Sharp 2007).

2. Some Buryat monks supported this "purification" — albeit for different reasons — calling for the return to the rules of the Vinaya (monastic code of early Indian Buddhism, which did not include the institution of reincarnation). Danzan Norbaev, an incarnate lama otherwise known as Ganzhurva-gegen, wrote a letter to the editor of the newspaper Buryat-Mongol Pravda, renouncing his status as an incarnate (Norbaev 1927).

3. Shortly after my last visit, Itigelov's body was moved into a new temple, specially constructed for him. The temple was named the Palace of Itigelov.

4. Interview, Ivolginsk monastery, 2008.

5. Similarly, the Russian Orthodox Church maintains that Lenin should be removed from the mausoleum and given a "proper human burial."

6. The Russian Orthodox Church also reports incorruptible bodies, such as the body of the saint Aleksandr Svirskii, who is sometimes mentioned in connection to Itigelov (Klin 2006). Svirksii's remains, however, are clearly treated as sacred relics; claims that he is alive are not made. Although Buryat Buddhism might have been influenced by Russia's dominant religion, it is the distinct pan-Buddhist conceptions of life, death, and the body that enable phenomena like Itigelov. Since the discovery of Itigelov, Buryat lamas have tried to find other incorruptible bodies by exhuming the bodies of previous Khambo Lamas (Buryatia had 23 Khambo Lamas, the current Khambo Lama being the 24th). Despite these efforts, no more incorruptible bodies were found (see Bernstein 2011).

7. Similar narratives of magical escape are also widespread in other post-Soviet contexts (Balzer 1997; Grant 2011).

8. It is well documented that various Central and Inner Asian peoples, both Turkic and Mongolian speaking, referred to Russian emperors as "White Tsars" (for detailed analysis of this phenomenon, see Trepavlov 2007). It is possible that Buryats' association of Russian emperors with White Tara is related to the notions of the "White Tsar."

9. Author interviews, 2009-10.

10. Although Buryats never developed a formal institution of reincarnation whereby a child is identified as a reincarnation of a previous lama, some prominent lamas were posthumously referred to as incarnates of past masters. 
11. Author interviews with Yeshe Lodoi Rinpoche (Buryatia, Russia, 2001), Kentul Rinpoche (present Galsan Legden; Karnataka, India, 2008), and Shivalkha Rinpoche (Karnataka, India, 2008). Galsan Legden is also briefly mentioned in the autobiography of Agvan Nyima (a Buryat monk-scholar who lived in Tibet and India) and by the Buryat researcher G. N. Zaiatuev, who mentions his name among a group of monks sent to Lhasa by the Buryat lama and diplomat Agvan Dorzhiev in 1927 (Nyima 1996:4; Zaiatuev 1991:42).

12. Empowerments are necessary to start practicing "deity yoga" — a distinctive tantric Buddhist meditative practice in which one visualizes oneself as being a buddha.

\section{REFERENCES CITED}

Agamben, Giorgio

1998 Homo Sacer: Sovereign Power and Bare Life. Stanford: Stanford University Press.

Anonymous

2002 Buriatiia otkazalas' ot suvereniteta. April 16, 2002. http://politsib.ru/news/? id $=3247$ \&print $=$ on, accessed August 2010.

2005 Buriatskii Lenin: interesnye i neob’'iasnimye fakty. http://www.koicombat. org/forum/viewtopic.php?f=7\&t=8709, accessed August 2009.

2006 Na sto grammov tiazheleet khambo lama Itigelov posle vstrech s veruiushchimi. Inform-Polis, May 17. http://www.infpol.ru/news/576/4638.php, accessed October 2009.

2007 Lenin, Mao i drugie mumii: kak khraniat znamenitye tela. http: / / www.topnews. ru/photo_id_891_1.html, accessed October 2009.

2009a Buddiiskie lamy ustroili prezidentu RF chaepitie. http://www.newsru.com/ religy/24aug2009/medvedev_sangha.html, accessed September 2009.

2009b Deputaty i politika: Narodnyi khural okonchatel'no lishil Buriatiiu suvereniteta no zato osudil neo-natsizm. Inform-Polis, November 11. http://www.infpol. ru/news/670/25123.php?sphrase_id=18932, accessed January 2010.

2009c Medvedev stal Beloi Taroi. Gazeta.ru. http://www.gazeta.ru/politics/2009/ 08/24_kz_3239833.shtml, accessed September 2009.

Attwood, Lynne

1990 The New Soviet Man and Woman: Sex-Role Socialization in the USSR. Bloomington: Indiana University Press.

Balzer, Marjorie Mandelstam

1997 Soviet Superpowers. Natural History 106(2):40-41.

2005 Whose Steeple Is Higher? Religious Competition in Siberia. Religion, State and Society 33(1):57-69.

Bataille, George

1991 The Accursed Share. New York: Zone.

Bernstein, Anya

2011 The Post-Soviet Treasure Hunt: Time, Space, and Necropolitics in Siberian Buddhism. Comparative Studies in Society and History 53(3): 632-653.

N.d. Religious Bodies Politic: Rituals of Sovereignty in Buryat Buddhism. Manuscript. Borneman, John, ed.

2004 Death of the Father. An Anthropology of the End of Political Authority. New York: Berghahn.

Buck-Morss, Susan

2000 Dreamworld and Catastrophe. The Passing of Mass Utopia in East and West. Cambridge, MA: MIT Press.

Cattelino, Jessica R.

2008 High Stakes: Florida Seminole Gaming and Sovereignty. Durham, NC: Duke University Press. 
Coffey, Wallace, and Rebecca Tsosie

2001 Rethinking the Tribal Sovereignty Doctrine: Cultural Sovereignty and the Collective Future of Indian Nations. Stanford Law and Policy Review 12(2):191-221.

Collins, Steven

1997 The Body in Theravada Buddhist Monasticism. In Religion and the Body. S. Coakley, ed. Pp. 185-205. Cambridge: Cambridge University Press.

Cuevas, Bryan J., and Jacqueline Ilyse Stone, eds.

2007 The Buddhist Dead: Practices, Discourses, Representations. Honolulu: Kuroda Institute with Hawaii University Press.

Dragadze, Tamara

1993 The Domestication of Religion Under Soviet Communism. In Socialism: Ideals, Ideologies and Local Practice. C. Hann, ed. Pp. 148-157. London: Routledge.

Erbanov, N. I.

1959 V chem vred religioznykh prazdnikov i obriadov lamaizma. Moscow: Obshchestvo po rasprostraneniu politicheskikh i nauchnykh znanii RSFSR.

Foucault, Michel

1979 Discipline and Punish. The Birth of the Prison. New York: Vintage Books.

1980 History of Sexuality. New York: Vintage Books.

2003 "Society Must Be Defended." Lectures at the Collège de France 19751976. New York: Picador.

Gal, Susan

1991 Bartók's Funeral: Representations of Europe in Hungarian Political Rhetoric. American Ethnologist 18(3):440-458.

Grant, Bruce

2011 Shrines and Sovereigns: Life, Death, and Religion in Rural Azerbaijan. Comparative Studies in Society and History 53(3):654-681.

Hansen, Thomas Blom, and Finn Stepputat

2004 Sovereignty Revisited. Annual Review of Anthropology 35:295-315.

2005 Introduction. In Sovereign Bodies: Citizens, Migrants, and States in the Postcolonial Period. T. B. Hansen and F. Stepputat, eds. Pp. 1-36. Princeton: Princeton University Press.

Kantorowicz, Ernst

1957 The King's Two Bodies. A Study in Mediaeval Political Theology. Princeton: Princeton University Press.

Kaufman, Sharon R., and Lynn M. Morgan

2005 The Anthropology of the Beginnings and Endings of Life. Annual Review of Anthropology 34:317-341.

Klin, Boris

2006 Zhivee vsekh zhivykh ne Lenin, a lama Itigelov. Izvestiia, November 8. http:// www.izvestia.ru/special/article3095502/, accessed October 2009.

Livers, Keith A.

2004 Constructing the Stalinist Body: Fictional Representations of Corporeality in the Stalinist 1930s. Plymouth: Lexington Books.

Lock, Margaret, and Judith Farquhar, eds.

2007 Beyond the Body Proper: Reading the Anthropology of Material Life. Durham, NC: Duke University Press.

Lopez, Donald S.

2002 The Story of Buddhism: A Concise Guide to Its History and Teachings, New York: HarperOne.

Luehrmann, Sonja.

2011 Secularism Soviet Style. Teaching Atheism and Religion in a Volga Republic. Bloomington: Indiana University Press. 
Mayakovsky, Vladimir

2003 [1924] Vladimir Ilyich Lenin: A Poem. Honolulu: University of Hawaii Press.

Mills, Martin A.

2000 Vajra Brother, Vajra Sister: Renunciation, Individualism and the Household in Tibetan Buddhist Monasticism. Journal of the Royal Anthropological Institute 6(1):17-34.

2002 Identity, Ritual and State in Tibetan Buddhism: The Foundations of Authority in Gelukpa Monasticism. London: Routledge.

Mukhanov, Igor'

2005 Dozhd' iz tsvetov: Buriatskie buddiiskie pritchi. Moscow: Agarti.

Norbaev, Danzan

1927 Pis'mo v redaktsiiu. Buriat-Mongol'skaia Pravda, 205, 11 September 1927, Razr. 2, Op. 1, \#374. St. Petersburg Orientalist Archive, St. Petersburg, Russia.

Nyima, Agvan

1996 Pereprava cherez reku sansary. Avtobiografiia. Ulan-Ude: TsDUB.

Pedersen, Morten

2011 Not Quite Shamans. Spirit Worlds and Political Lives in Northern MonRogers, Douglas golia. Ithaca: Cornell University Press.

2005 Introductory Essay: The Anthropology of Religion after Socialism. ReliSharp, Leslie A. gion, State, and Society 33(1):5-18.

2007 Commodification of the Body and Its Parts. Annual Review of Anthropology 29:287-328.

Starks, Tricia

2008 The Body Soviet: Propaganda, Hygiene, and the Revolutionary State. Madison: University of Wisconsin Press.

Steinberg, Mark D., and Catherine Wanner, eds.

2008 Religion, Morality, and Community in Post-Soviet Societies. Washington, DC: Woodrow Wilson Center Press.

Taussig, Michael

1998 Transgression. In Critical Terms for Religious Studies. M. C. Taylor, ed. Pp. 349-365. Chicago: University of Chicago Press.

Todorova, Maria N.

2009 Bones of Contention: The Living Archives of Vasil Levski and the Making of Bulgaria's National Hero. Budapest: Central European University Press.

Trepavlov, V. V.

2007 "Belyi tsar'." Obraz monarkha i predstavlenie o poddanstve u narodov Rossii XV-XVII veka. Moscow: Vostochnaia literatura.

Tsyrempilov, N. V.

2009 Za sviatuiu dkharmu i belogo tsaria. Rossiiskaia imperiia glazami buriatskikh buddistov XVIII — nachala XX vekov. Ab Imperio 2:105-130.

Tumarkin, Nina

1997 Lenin Lives! The Lenin Cult in Soviet Russia. Cambridge, MA: Harvard University Press.

Verdery, Katherine

1999 The Political Lives of Dead Bodies. Reburial and Postsocialist Change. New York: Columbia University Press.

Vitebsky, Pier

1995 The Shaman. Boston: Little and Brown.

Williams, Paul

1989 Mahāyāna Buddhism. The Doctrinal Foundations. London: Routledge. 
1997 Some Mahayana Buddhist Perspectives on the Body. In Religion and the Winegar, Jessica Body. S. Coakley, ed. Pp. 205-231. Cambridge: Cambridge University Press.

2006 Cultural Sovereignty in a Global Art Economy: Egyptian Cultural Policy and the New Western Interest in Art from the Middle East. Cultural Anthropology 21(1):173-204.

Zaiatuev, G. N.

1991 Tsanid-khambo Agvan Dorzhiev, 1853-1938. Ulan-Ude.

Editors' Notes: Cultural Anthropology has published a number of articles on postsocialism, including Smoki Musaraj's "Tales from Albarado: The Materiality of Pyramid Schemes in Postsocialist Albania” (2011), Dominic Boyer and Alexei Yurchak's "American Stiob: Or, What Late-Socialist Aesthetics of Parody Reveal about Contemporary Political Culture in the West" (2010), and Nancy Ries's "Potato Ontology: Surviving Postsocialism in Russia" (2009).

Cultural Anthropology has also published articles on Buddhism. See, for example, Ernestine McHugh's "Contingent Selves: Love and Death in a Buddhist Society in Nepal” (2002) and Robert Desjarlais's “Echoes of a Yolmo Buddhist's Life, in Death" (2000). 